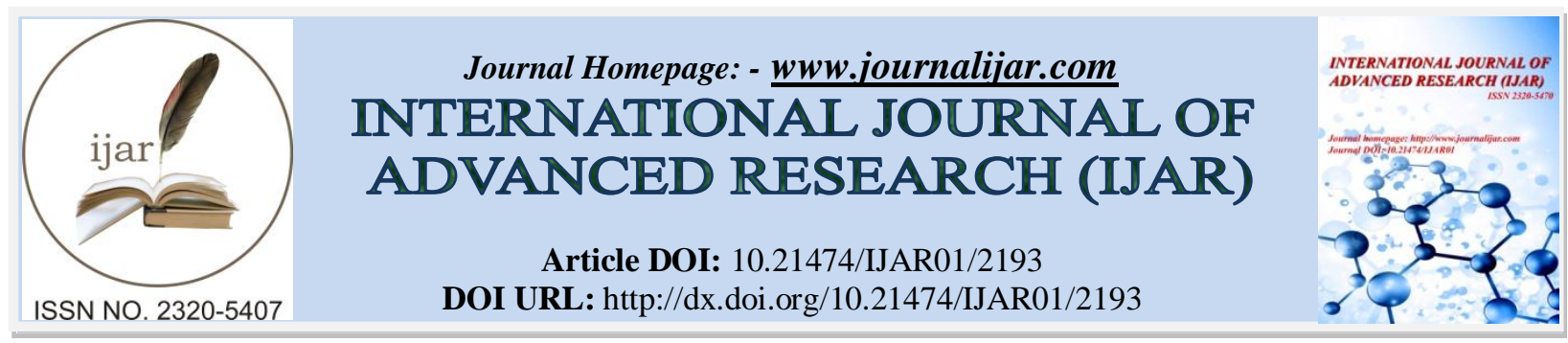

RESEARCH ARTICLE

\title{
STRUCTURAL-SEMANTIC ANALYSIS OF ANALYTICAL CONSTRUCTION VERB + VERB IN UZBEK AND ENGLISH LANGUAGES.
}

"Shakhnoza Rustamovna Mustanova.

Senior Research fellow at Samarkand State Institute of Foreign Languages, Samarkand, Uzbekistan.

\section{Manuscript Info}

Manuscript History

Received: 27 September 2016

Final Accepted: 30 October 2016

Published: November 2016

Key words:-

Analytical construction, verbal, delexicalized, verbal noun, semantic

characteristic, auxiliary verb, incompleteverb.

\section{Abstract}

Analytical constructions in languages represent a particular type of word combination that seems similar to some other language phenomenon, such as free word combinations, compound verbs, and idiomatic expressions. However, due to their distinguished features they are separated from them. Analytical constructions in Uzbek and English languages though different in many aspects are apparently in one type. That is verbal analytical construction consisting of a delexicalized or light verb and the verbal(Infinitive, Participle II, Participle III). In this article we analyze and compare this type of word combination from structural-semantic aspect.

Copy Right, IJAR, 2016,. All rights reserved.

\section{Introduction:-}

Studying analytical constructions in the light of semantics is closely connected with the research of lexical-semantic factors influencing syntactic derivation. To this regard, A.I Smirnitskiy notes: "Formulae of construction structure are the same for sentence construction formulae in those cases when the latter are one-member, as well as the formulae within more complex sentence structures as separate components or expanders"(Smirnitskiy, 1959). Formulae of idiomatic phrase structures cannot be interrelated to the sentence structure formulas, as they partially lose their specific character ".

Modern English language with its analytical grammatical built is characterized with active interaction between lexical and grammatical phenomena. In many cases, lexical and grammatical spheres precondition each other.

Word combination is a syntactical and structural-content oriented unity within a sentence. Word combination is formed basing on syntactical collocability of words. "Separate words are linked to each other, first of all basing on their meaning. Such a unity of the lexical meanings of the constituents of word combinations is possible because the connection and relationships between objects and phenomena of the real world are reflected in our consciousness. Some words are linked to each other only there where there is certain connection between appropriate objects and phenomena of objective reality" (Smirnitskiy, 1959). In combinations, words are characterized with certain relationships that must be taken into account when conducting analysis of analytical constructions of any type.

\section{Analysis:-}

Due to the differences in the structures of Uzbek and English languages, one and the same linguistic term expresses different notions. For example, the term verbal analytical constructions is used to denote the type of word combination which consists of a participle of the notional verb with the endings $-(\mathrm{i}) \mathrm{b},-\mathrm{a},-\mathrm{y}+$ delexicalized auxiliary verb(Axtamova X.T., 1981). However, in English not only the constructions of the model Verb + Gerund 
or Verb + to Infinitive (keep doing, come to know, grow to understand, etc.) are called analytical, but also those that are made up of Light verb+ deverbal Noun (Shaabdurakhmonov Sh., 1981). Usually, that construction has a synonymic verb with the same meaning (to have a rest - to rest, to make a decision-to decide).

Interesting is that, the same type of construction in Uzbek is defined as a compound verb (dam olmoq, qaror qilmoq) (Shalamov Yu.V., 2001).

Semantics of the construction under discussion in this article directly depends not only on the meaning of the leading element which is the notional verb in the form of Participle, Gerund or Infinitive, but also on the meaning of the dependent element expressed by the delexicalized verb in both languages.

In the modern Uzbek language, auxiliary and incomplete verbs function as dependent elements. Auxiliary verbs demonstrate various characteristics of actions and express modal meanings.

Uzbek does not have fully auxiliary verbs. In other words, there are no verbs in this language that completely lost their lexical meaning and are only used as auxiliary verbs. Some notional verbs can be used as auxiliary verbs too.

Every auxiliary verb has its own meaning as well as its distinguishing features. But there are qualities general for all of them.

The auxiliary verb is connected to the notional verb expressed by the Participle form ending with (i)b, -a,-y. Not all verbs can collocate with any type of the Participle. For example, the verb "ber" (give) can be combined with the Participle ending with all three affixes, while 'qara' (look) collocates only with Participle ending with -(i)b, and 'yoz' (write) collocates with the Participles ending with -a. See: 'yozib ber', 'borib qara' (Shaabdurakhmonov Sh., 1981).

In the modern Uzbek language the main group of auxiliary verbs forming verbal analytical constructions consists of those verbs, whose collocability is limited with Participles ending with (i)b, and only three verbs combine with Participle ending with -a, -y: 'boshla', 'bil', 'yoz'. For example, 'ayta boshladi' (started to tell), 'yoza bildi' (managed to write), 'yiqila yozdi' (almost fell).

Here, we must mention, that auxiliary verbs that can collocate with Participles ending with (i)b, -a, and -y, their meaning in each is different. See for example, 'yozib oldi' (wrote down), 'yoza oldi' (was able to write), 'kelib qoldi' (came unexpectedly somewhere), 'kela qoldi' (finally came).

Auxiliary verbs can be monosemantic or polysemantic, and their meanings are realized in contexts.

For example:

Sabr qil, khotin, yeb turgan go 'shtimiz bor. O'g'ling kelsa so'yamiz deb ko'nglimdan o'tkazib qo'yibman.

Go 'zal qo'lidagi gulini adashib qoldimi, ona tili o'qituvchisiga berib qo'ydi.

\section{Results and discussion:-}

A particular interest arises from the fact that auxiliary verbs forming verbal analytical construction in Uzbek vary in the verbs whose Participle they can collocate with. That is some verbs (for example, boshla) can be combined with Participles of almost all notional verbs, while others, for example yoz, are limited in this. Such a limitedness or unlimitedness in combinability is determined with their semantics.

Having studied the semantics of some of the most frequently used in analytical constructions auxiliary verbs; we came to the following conclusions concerning their combinability and semantics:

1) 'boshla' (start, begin) can collocate with the Participle of the notional verb ending with -a, -y and expresses the beginning of the action: 'yoza boshladi' (started to write), 'gapira boshladi' (started to speak), 'o'qiy boshladi' (started to read), and etc. For example: Elmurod dunyo xabarlaridan o'qib bera boshladi (Elmurod started to read aloud the world news).

2) 'yot' (lie)can combine with the verb ending in -(i)b and expresses the duration of the action: Daryodan suv chiqarishga urinib yotishibdi (They are keeping trying to find water) .

3) 'tur' (stand, stay) can collocate with both forms of participle and expresses the following meanings: 1) in combination with the participle ending with -(i)b: a) duration of the action for a limited length of time: Sidiqjon 
.. qizini kuzatib turar edi (Sidiqjon ... was observing his daughter). Ko'nglinda qanday o'y borligi ko'zingdan $k o$ 'rinib turibdi; b) the action happening for a limited amount of time only while another action is happening, that is "temporally". See the example: I will take care of the trees while you are studying. 2) if the verb 'tur' (stay, stand) combines with the participle ending with $-\mathrm{a},-\mathrm{y}$, it expresses the following meanings: a) the action happening prior to another: 'bora tur' (stay going), 'yoza tur' (stay writing), 'o'qiy tur (stay reading); b) with the verbs bil, see, be, it expresses the action which happens despite another one: Ergashning xulqini bila turib unga bir og'iz shipshitib qo'ymaganiga endi qattiq o'kindi (He regretted he had not talked to him despite knowing his behavior.).

4) 'yur' (walk) can collocate with participles ending with -(i)b meaning the followings: a) the extensive duration of the action: O'rmonjon xo'p ham to'lib-toshib yurgan ekan, yuragini rosa bo'hsatdi. (O'rmonjon was apparently so full of it, he just poured out his heart); б) the action which is not good to fulfill and therefore, should not be done: To'y qiziganda yana biror bir baloni boshlab yurma-deb To'lamat mo'ylov Qo'chqorga qo'l chuzdi (And don't start something wrong when the wedding is at the height - said To'lamat mo'ylov, and stretched out his hand to Quchqor).

5) 'o'tir' (sit) collocates with participles ending with -(i)b, and just as the verbs 'yot', 'tur', and 'yur', it also expresses lasting action, but in contrast to them, it partially preserves its lexical meaning which often causes difficulties to clarify whether it functions as a notional or auxiliary verb in such analytical constructions as 'yozib o'tirmoq', 'ishlab o'tirmoq': Qiya stollardan ikkitasida ikki yigit boshini ko 'tarmay ishlab o'tirishibdi (On two of the slanting desks, two young men were sitting working); b) it adds to the meaning of the notional verb the connotation of undesirability of doing the action, and the person expressed by the subject does not approve doing it: Men sodda shuning gapiga ishonib o'tiribman (Artless me, I trusted him).

6) 'bor' (go) collocates with participles with all three endings; in all combinations they express gradual action fulfillment: Kundan-kunga Zaynabning sussayib o'ziga begonalashib borganini yaxshi anglar edi (Day by day he realized how weak Zaynab was getting and how was growing apart from him).

7) 'kel'(come) collocates with participles ending with -(i)b and expresses the lasting action with the shade of spatialy or temporaly oriented meaning: Necha yillardan beri saqlanib kelayotgan ezgu armonlar uning butun asablarini uyg'otib yuborgan edi (All those dreams he has had for years have excited his mind). Endigina ko'tarilib kelayotgan oftob uning tiniq betide oynadek yaltirab ko'zni olaman deydi (The sun which was just rising shined on her spotless face.).

8) 'bo'l' (be) collocates with participles ending with -(i)b and renders the following meanings: a) completeness of the action expressed with the notional verb: Bunday paytlarda u, to qo'lini yuvib bo'lmaguncha, kasalga orqasini o'girib turar edi (At such times she used to turn her back to the sick). b)existence of possibility to do the action (in negative form - absence of that possibility: Hamma imni faat savod orqaligina o'rganib bo 'ladi (All science can be learned by education) Chanqoqni tomchi bilan qondirib bo'lmaydi (Thirst cannot be slaked with a drop).

The same meaning can be expressed with the phrase containing the verb 'ol' (take) as auxiliary (yoza olmoq- yozib bo'lmoq) but with the shift of meaning in the semantics of the whole construction. In other words, the phrase yoza olmoq expressed ability of the subject to fulfill the action, while in yozib bo'lmoq, the possibility of fulfilling the action comes from outside the subject.

In the English language, the analogical construction (Verb + verb) is also quite productive and widely-used. If we analyze the model from the point of view of light verbs most frequently used in it, we can see that some of those verbs are equivalents to the Uzbek auxiliary verbs studied above.

Depending on the form of the form of the second element (notional verb) verbal analytical construction can be divided into following three groups: Verb + to Infinitive, Verb + Gerund, and Verb + Participle II.

In this article we shall analyze only one of them, the model Verb+to Infinitive and four verbs that come most often in it. They are the following light verbs: COME, GROW, GET, START.

Just as the light verb constructions in Uzbek, the semantics of the construction in English largely depends on the semantics of the light verb.

For example, Plotkin V.Ya. in his article "O putyax evolyutsii analitizma v germanskix yazikax" [4] writes that the verb 'to come' in its semantic field contains the information about a point in the time continuum when the agent 
enters a quite definite space, while the verb 'go' expresses that the agent is deprived of a stable spatial state. I.V. Shaposhnikova distinguishes their categorical meanings: COME - "action oriented at achieving some stable spatial position », GO - action oriented at "depriving the subject of the stable spatial position"» (Shaposhnikova I.V., 2003). These meanings remain unchanged in any possible valence explication and determine the semantics of the phrase as a whole.

The verb 'come' in light verb construction COME + toV, expresses the beginning of a new situation: come to know/hat ("the situation when the subject knows/hates started") and contains aspectual meaning of effectiveness pointing out not the moment, but the fact that the subject passes into the acting state (now the subject knows/hates). Longman Dictionary of Contemporary English gives the following interpretation of the meaning of these constructions: to begin to have a feeling or opinion. E.g., He came to think of Italy as his home (LDCE, 2007)

The light verb GROW unites an acting component denoting spatial and qualitative state, acquiring the meaning of "lasting action targeted at changing the state of the subject".

In the expression the verb GROW expresses gradual entrance into a state, and the contexts may have adverbs clarifying the time or the quality of entering, such as slowly, one day, and etc. Thus the construction acquires aspectual meaning of slow entrance into acting state. In other words, the subject gradually collects knowledge (grow to know), feelings (grow to love). Longman dictionary of contemporary English gives the following definition of this construction: to gradually change your opinion and have a feeling that you did not have before. For example, After a while, the kids grew to like Mr. Cox[7].

Now, let us analyze the construction GET+toV, which contains three aspectual meanings in its semantics, expressing entering a new stage of acting state, which is qualitatively different from the previous one and leads to not only the achievement of the result but also to the effort necessary for this transfer which, in its turn, requires some time. The dictionary gives the following interpretation of the construction: to gradually begin to like, know, or understand someone or something. See the example: It will take a while for you to get to know everyone[7]

\section{Conclusion:-}

As we see this model of light verb construction is as productive in English as in Uzbek. Both in the Uzbek and in the English languages the semantics of the whole construction depends on the semantics of each of the components. Thought delexicalized or light verbs are considered to have lost some of their lexical meaning, the remaining part of it does influence the formation of the meaning of the construction in the languages under discussion.

\section{List of the literature used:-}

1. Smirnitskiy A.I. Morphologiya angliyskogo yazika (Morphology of English) (Moscow, 1959). .

2. Axtamova X.T. Posleslojniye formi in modern literary Uzbek language (Postpositive forms in modern literary Uzbek language). Abstract of the doctoral thesis. - Tashkent (1981).

3. Shaabdurakhmonov Sh. Modern Uzbek literary language //Tashkent: O'qituvchi.- 1980. 448 p.

4. Shalamov Yu.V. K problem analytizma morfologiyi I sintaksisa angliyskogo yazika (To the problem of analytism in morphology and syntax of the Englis language)// Lingvisticheskiye issledovaniya. To the $75^{\text {th }}$ anniversary of Professor V.G. Gak. Dubna: Fenix, 2001. P. 138-150.

5. Plotkin V.Ya. O putyax evolyutsii analytizma $v$ germanskix yazikax (About the evolution ways of analytism in Germanic languages)// Vzaimodeystviye yazikovix struktur v sisteme. Leningrad.: LGU, 1980..

6. Shaposhnikova I.V.Glagolnaya analiticheskaya nomitatsiya kak teoreticheskaya I metodologicheskaya problema v sovremennom angliyskom yazike (Verbal analytical nomination as theoretical and methodological problem in modern English)// Teoriya, istoriya, tipologiya yazikov: materials from readings for the memory of V.N. Yartseva Volume 1. - M. 2003.P. 202-211.

\section{Dictionaries:-}

1. Longman Dictionary of Contemporary English(LDCE). (2007)- Pearson Education Limited. - Edinburgh Gate, England.- 1949p. 